\title{
A case of fatal peripartum cardiomyopathy
}

Sir,

In 1970 you published a report by myself and colleagues from this hospital on a case of fatal peripartum cardiomyopathy. ${ }^{1}$ Since then, our patient's younger sister has died at the age of 31 at another hospital of dilated cardiomyopathy. An older sister developed congestive heart failure after delivery of a son at the age of 38 but she recovered. This son developed congestive heart failure at the age of 12 and was investigated by paediatricians at this hospital. He was found to have a dilated cardiomyopathy associated with serological evidence of recent Coxsackie virus infection and has been treated by cardiac transplantation. His younger brother developed heart failure attributed to cardiomyopathy and died nearly two years after operation for closure of persistent ductus. The case of the 12 year old boy will be reported by Dr Rosemary Rayner who will describe the family history and dis- cuss the interrelation of genetic and environmental factors in the genesis of dilated cardiomyopathy.

In our original article we stated that in our patient's case there was no family history of heart disease. The purpose of this letter is to correct this statement retrospectively, in the light of these later developments.

\section{Honey,}

Brompton Hospital,

Fulham Road,

London SW3 6HP.

\section{Reference}

1 Hughes RAC, Kapur P, Sutton GC, Honey M. A case of fatal peri-partum cardiomyopathy. Br Heart $\mathcal{f} 1970$; 32: 272-6.

\section{Notices}

\section{Electrocardiology in Amsterdam}

A symposium in honour of the late Professor Dirk Durrer on 35 Years of Electrocardiology in Amsterdam will be held at the Royal Tropical Institute, Amsterdam, on 29 and 30 May 1986. Further information may be obtained from: Dr Frits L Meijler, Interuniversity Cardiology Institute, Catharijnesingel 101, 3511 GV Utrecht, The Netherlands.

\section{British Cardiac Society}

The Annual General Meeting for 1986 will take place in York on 2 and 3 April 1986, and the closing date for receipt of abstracts will be 2 January 1986. 